J. Perinat. Med. 10 (1982) 273

\section{Vacuum extraction and neonatal jaundice}

\author{
I. Arad, P. Fainmesser, A. Birkenfeld, B. Gulaiev, E. Sadovsky
}

Departments of Pediatrics, Obstetrics and Gynecology, Hadassah University Hospital, Ein Karem Jerusalem, Israel

\section{Introduction}

Since the introduction of the modern vacuum extractor by MALMSTRÖM in 1954 [15], the procedure of vacuum extraction has gained increasing popularity $[2,16,17,19,20]$. During the extraction forces of negative outward suction and downward traction are always applied to the fetal scalp whereas shearing and circular forces are only occasionally exerted $[13,18]$. These forces invariably result in the formation of an edematous, occasionally ecchymotic, area called chignon directly beneath the vacuum cap. The incidence of other lesions such as cephalhematomata, abrasions and lacerations and subcutaneous ecchymoses varied in different reports [18], however significant lesions of the fetal scalp may mount to about $20 \%$ of vacuum extraction deliveries [1,17]. More serious complications as subgaleal bleeding and intracranial hemorrhage rarely occur [18].

It is conceivable, therefore, that blood sequestered in these lesions could result in an increased bilirubin load on the functionally limited neonatal liver leading to the development of hyperbilirubinemia. The present study was undertaken in order to compare bilirubin levels of vacuum extracted neonates with those of non-instrumentally delivered babies during the first 72 hours of life.

Since controversy exists with regard to the effect of oxytocin induction of labor on the course of neonatal jaundice $[3,4,8,11,21]$ we have also analyzed the effect of oxytocin induction on the bilirubin levels of our patients.

\section{Curriculum vitae}

Dr. ILAN ARAD graduated from the Hebrew University - Hadassah Medical School, Jerusalem, Israel, in 1970. Pediatric residency at the Hadassah University Hospital and at Rainbow Babies and Childrens Hospital, Case Western Reserve University, Cleveland, Ohio. Fellowship in Neonatal-Perinatal Medicine

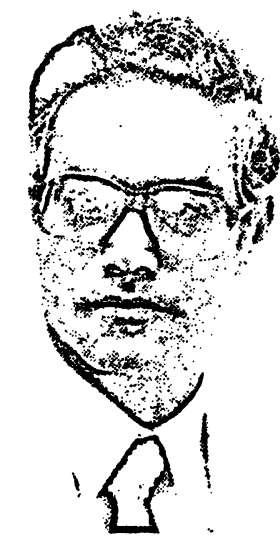
at The Children's Hospital of Philadelphia and The Hospital of The University of Pennsylvania. Diplomate of The American Board of Pediatrics with Competence in Neonatal-Perinatal Medicine (1979). Senior Neonatologist, Department of Pediatrics, Hadassah University Hospital. Lecturer at the medical school of The Hebrew University. Main research interest: Ascorbic acid in Brain Damage.

\section{Patients and methods}

One hundred and forty newborns who were the products of normal vaginal delivery or were delivered by vacuum extraction in the Obstetric Ward, Hadassah University Hospital, Ein Karem, Jerusalem, Israel from January through July 1980 were randomly selected for this study. All babies were screened for blood group incompatibilities and G6PD deficiency, and when found positive, excluded from the study as were neonates who had a complicated postnatal course. Only 125 neonates fulfilled the criteria for inclusion in the

$0300-5577 / 82 / 0010-0273 \$ 02.00$

(c) by Walter de Gruyter \& Co. · Berlin - New York 
study and were divided into four groups according to the onset of labor and mode of delivery:

1. Normal vaginal delivery following a spontaneous onset of labor $(n=35)$.

2. Normal vaginal delivery following inductions of labor by oxytocin drip $(n=21)$.

3. Vacuum extraction following a spontaneous onset of labor $(n=32)$.

4. Vacuum extraction following induction of labor by oxytocin drip $(n=37)$.

The indications for using the vacuum extractor were mild fetal distress in the second stage of labor or no progress of labor.

Oxytocin, for the induction of labor, was administered intravenously by drip infusion at an initial rate of 2-3 milli-units per minute, which was gradually increased until the appearance of effective contractions, usually at a rate of 7-9 milliunits per minute.

All gestations were uncomplicated and of 37 weeks duration or more, as calculated from the menstrual history and ascertained by the DoBOwITz score
[9]. All birth weights were above $2.5 \mathrm{~kg}$ and the initial APGAR scores were 7 or above. There were no significant differences of birth weight, gestational age and initial APGAR scores among all the study groups. After obtaining a parental consent, total venous blood bilirubin was measured daily during the first 72 hours, which is the usual postnatal stay in our ward, or more as required. Light therapy was applied according to published guidelines for phototherapy [14].

\section{Results}

Of the 125 deliveries, 56 were normal and 69 were terminated by vacuum extraction. Fig. 1 demonstrates that infants delivered by vacuum extraction developed significantly higher bilirubin levels than neonates who had a noninstrumental vaginal delivery; the significance of the difference becoming greater toward 72 hours of age.

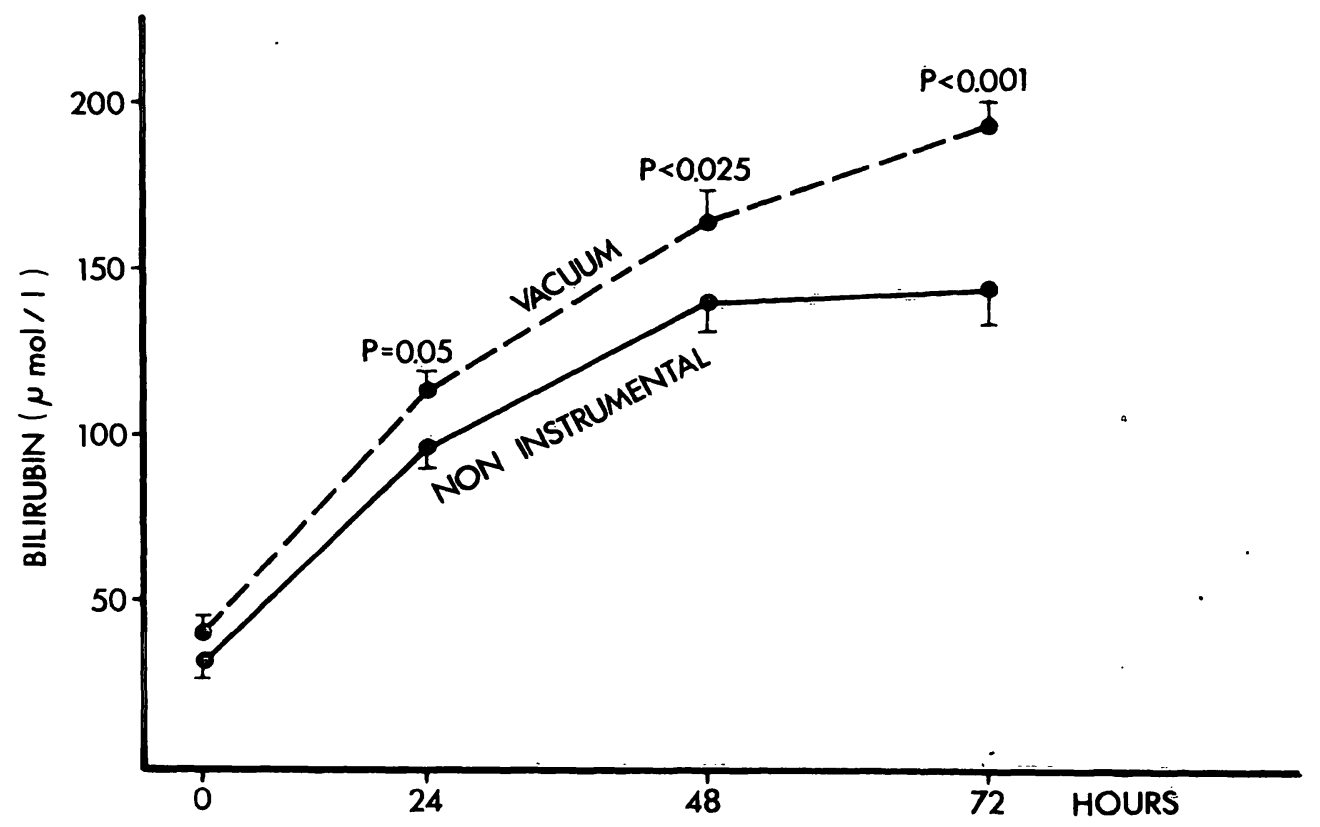

Fig. 1. Bilirubin levels of vacuum delivered neonates versus non instrumentally delivered neonates (Mean \pm S.E.M.)

Fig. 2 depicts bilirubin levels according to whether or not oxytocin induction was applied during delivery. Non-induced vacuum delivered babies ( $\mathrm{n}=32$, mean birth weight $=3.33 \mathrm{~kg}$ ) had higher bilirubin levels at 24,48 , and 72 hours $(P<0,05$, $\mathrm{P}<0.05$ and $\mathrm{P}<0.005$ respectively) than non induced, non instrumentally delivered neonates
( $\mathrm{n}=35$, mean birth weight $3.22 \mathrm{~kg}$ ). Induced vacuum delivered infants ( $\mathrm{n}=37$, mean birth weight $3.32 \mathrm{~kg}$ ) had higher bilirubin values at 24 , 48 and 72 hours of age $(P<0.05, P<0.05$ and $P<0.001$ respectively) than induced noninstrumentally delivered babies ( $\mathrm{n}=21$, mean birth weight $3.20 \mathrm{~kg}$ ). 


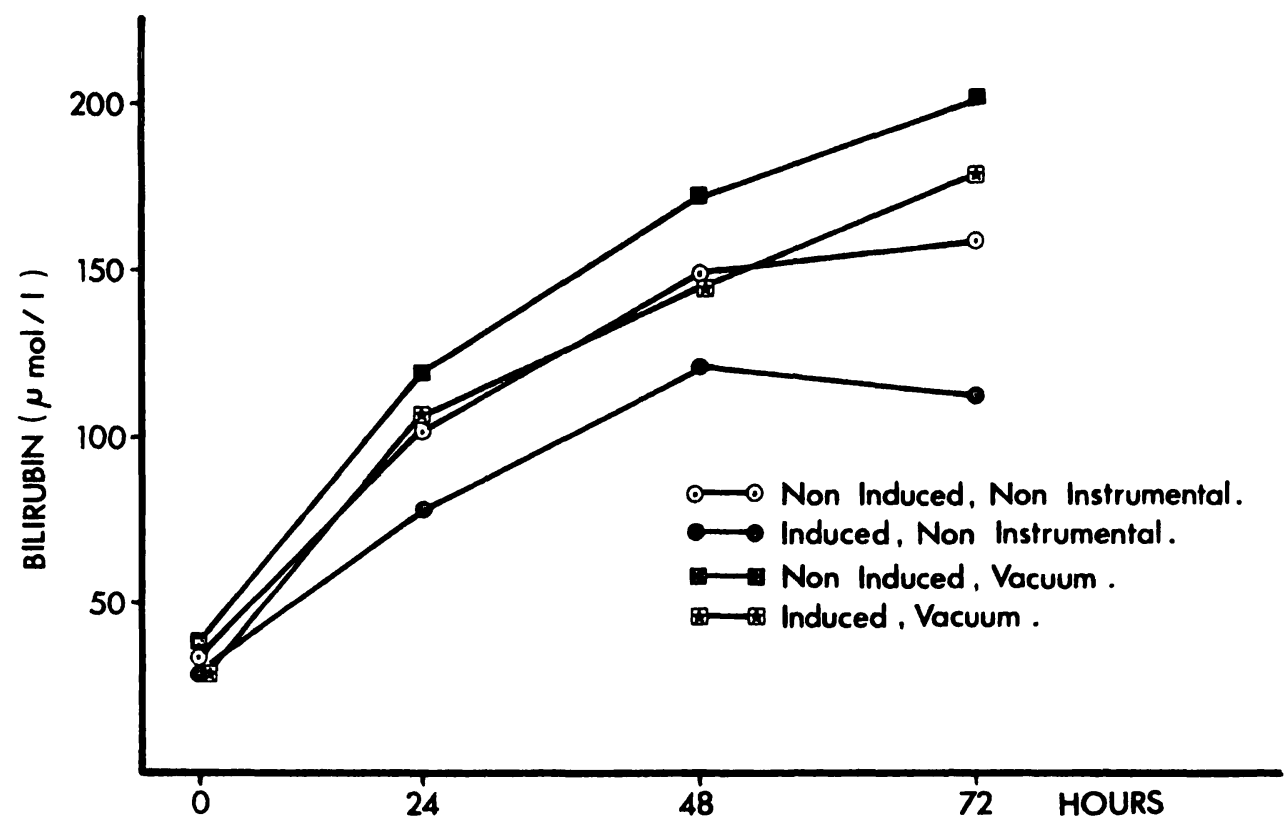

Fig. 2. Bilirubin levels of neonates according to mode of delivery, including babies receiving phototherapy

The association between oxytocin induction and neonatal jaundice was analyzed within both the vacuum and non instrumentally delivered groups. Induction with oxytocin was associated with lower bilirubin levels at 24 and 48 hours $(\mathrm{P}<0.05)$ in the vacuum group and at 24,48 and 72 hours ( $\mathrm{P}<0.01, \mathrm{P}<0.05$ and $\mathrm{P}<0.005$ respectively) in the non-instrumentally delivered group.

Considering th effect of light on the course of neonatal jaundice our data were also analyzed excluding these infants who were subjected to phototherapy (Fig. 3). Vacuum extracted babies had significantly higher bilirubin levels at 24 and 72 hours than the non-instrumentally delivered babies whether induced by oxytocin or not. The $P$ values were $<0.02$ and $<0.01$ respectively for the induced babies and $<0.05$ and $<0.005$ respectively for the non induced groups. Induction with oxytocin was associated with a significantly lower bilirubin level only at 24 hours of age in the non-instrumentally delivered group $(P<0.05)$ whereas no significant differences of bilirubin levels were observed within the vacuum extracted group.

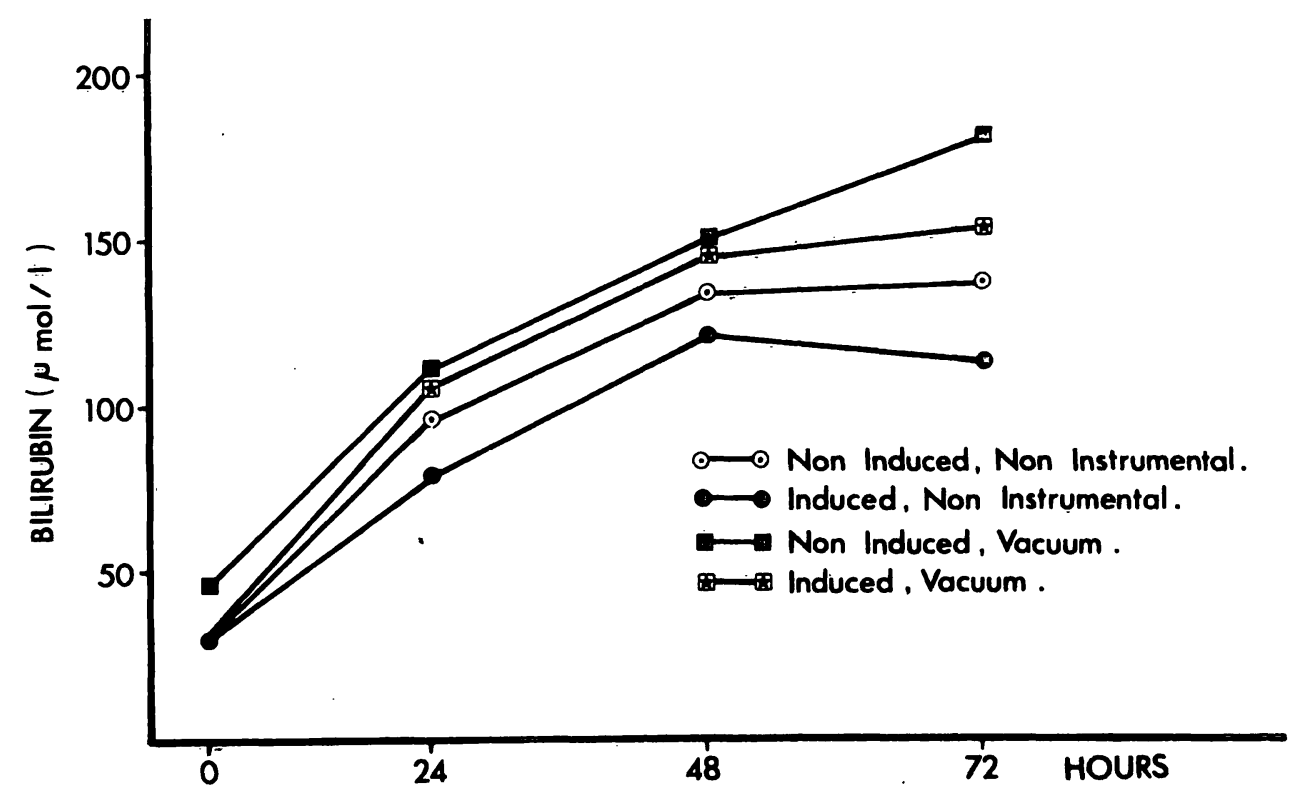

Fig. 3. Bilirubin levels of neonates according to mode of delivery, not including babies receiving phototherapy 
The incidence of phototherapy applied in the various study groups was evaluated by the $x^{2}$ and FISHER exact tests (Tab. I). Vacuum extracted babies required more phototherapy than the noninstrumentally delivered infants. This difference was mainly due to the absence of phototherapy cases in the induced non-instrumentally delivered group.

Tab. I. The incidence of phototherapy according to the mode of delivery

\begin{tabular}{lllll}
\hline Mode of delivery & $\begin{array}{l}\text { Total } \\
\text { No. of } \\
\text { Cases }\end{array}$ & $\begin{array}{l}\text { No. of } \\
\text { Photo- } \\
\text { therapy } \\
\text { Cases }\end{array}$ & P Value \\
\hline Vacuum \pm oxytocin & 69 & 19 & 27.5 & $<0.04$ \\
Normal \pm oxytocin & 56 & 7 & 12.5 & \\
Normal + oxytocin & 21 & 0 & 0 & $<0.03$ \\
Normal & 35 & 7 & 20 & \\
Vacuum & 32 & 9 & 28.1 & N.S. \\
Normal & 35 & 7 & 20 & \\
Vacuum + oxytocin & 37 & 10 & 27 & N.S. \\
Vacuum & 32 & 9 & 28.1 & \\
Vacuum + oxytocin & 37 & 10 & 27 & $<0.01$ \\
Normal + oxytocin & 21 & 0 & 0 & \\
\hline
\end{tabular}

\section{Discussion}

The results of our study indicate that delivery by vacuum extraction is associated with higher bilirubin levels during the first 72 hours of life than non-instrumental vaginal delivery. Such trend was evident in both the oxytocin induced and noninduced infants and was also supported by the higher incidence of phototherapy cases among the vacuum extracted group. As a result the clinician attending newborn babies should be aware of the

\section{Summary}

Various fetal scalp lesions are related to the use of the vacuum extractor. Blood sequestered in these lesions could result in an increased bilirubin load on the functionally limited neonatal liver, leading to the develop- higher incidence of neonatal hyperbilirubinemia associated with vacuum extraction. GREIS et al. [12] found a similar incidence of jaundice in both vacuum extracted neonates and their controls delivered by Cesarean section. However, their definition of jaundice as "clinically recognizable or else suggested by serum bilirubin level greater than $6 \mathrm{mg} / \mathrm{dl}$ " does not really allow for an accurate comparison of the different methods of delivery. Others have reported an increased incidence of neonatal jaundice associated with vacuum extraction [1]. A likely explanation for our observation may well be an increased bilirubin load resulting from the sequestration of blood in the common scalp lesions present with vacuum extraction delivery [18]. It is interesting to note that fetal scalp damage resulting in neonatal jaundice can be caused also by a fetal scalp electrode [7].

The association of oxytocin induction of labor and neonatal jaundice is still a matter of controversy $[3,4,5,6,8,10,11,21]$. It has been suggested that hyperbilirubinemia may result from an increased rate of red cell breakdown and hemoglobin catabolism secondary to increased intensity of uterine contractions [8] or decreased erythrocyte deformability [3]. Others have speculated that oxytocin induction before the actual start of labor may be associated with a lack of hormonal surge present at spontaneous delivery, and hence a reduced activity of hepatic enzymes involved in bilirubin metabolism $[4,5,6]$. Our results, in accordance with others $[10,11,21]$, failed to show any positive correlation between oxytocin induction and neonatal hyperbilirubinemia. Moreover, analysis of the results, - including phototherapy cases, indicated that oxytocin induction was associated with an attenuation of bilirubin levels both when vacuum extraction or spontaneous deliveries occurred. We do not have an explanation for this observation, which, unfortunately, adds little to the settlement of the oxytocin controversy.

ment of hyperbilirubinemia. In the present study bilirubin levels of vacuum extracted neonates were compared with those of non-instrumentally delivered babies during the first 72 hours of life. Sixty-nine vacuum ex- 
tracted neonates had higher bilirubin levels than 56 noninstrumentally delivered babies at 24 (114 $\mu \mathrm{mol} / 1 \mathrm{vs}$. $96 \mu \mathrm{mol} / \mathrm{l}), 48$ (163 vs. 141$)$ and 72 (194 vs. 144) hours of age. The $p$ values were $0.05,<0.025$ and $<0.001$ respectively. This trend was apparent in both oxytocin induced and non-induced deliveries and whether or not phototherapy cases were included in the analysis. The incidence of hyperbilirubinemia requiring phototherapy

Keywords: Bilirubin, jaundice, vacuum.

\section{Zusammenfassung}

\section{Vakuumextraktion und Neugeborenenikterus}

Verschiedene Kopfhautverletzungen beim Neugeborenen hängen mit dem Gebrauch der Saugglocke zusammen. Hierdurch bedingte Blutungen führen über einen Bilirubinanstieg, der von der begrenzten funktionalen Kapazität der Neugeborenenleber nicht bewältigt werden kann, zur Hyperbiliruninämie.

In der vorliegenden Untersuchung haben wir die Bilirubinspiegel von Kindern, die mit dem Vakuumextraktor entwickelt wurden, verglichen mit denjenigen von Kindern, die spontan geboren wurden. Dabei wurden die ersten 72 Lebensstunden berücksichtigt. 69 mit der Saugglocke entwickelten Kinder hatten höhere Bilirubinspiegel als 56 spontan geborene Kinder, und zwar nach 24 Stunden (114 $\mu \mathrm{mol} / 1 \mathrm{zu} 96 \mu \mathrm{mol} / \mathrm{l}), 48$ Stunden $(163 \mu \mathrm{mol} / \mathrm{l} \mathrm{zu}$ $141 \mu \mathrm{mol} / \mathrm{l})$ und 72 Stunden $(194 \mu \mathrm{mol} / 1 \mathrm{zu} 144 \mu \mathrm{mol} / \mathrm{l})$.

Schlüsselwörter: Bilirubin, Ikterus, Vakuumextraktion.

\section{Résumé}

Extraction par ventouse et ictère néonatal

On a rapporté à l'utilisation de la ventouse diverses lésions du scalp foetal. Le sang épanché au niveau de ces lésions peut amener une surcharge de bilirubine pour le foie du nouveau-né, limité sur le plan fonctionnel, conduisant à l'apparition d'une hyperbilirubinémie. Dans cette étude les auteurs ont comparé les taux de bilirubine au cours des 72 premières heures des nouveaux-nés extraits à l'aide de ventouse aux taux de ceux nés sans manoeuvre instrumentale. 69 nouveauxnés extraits par ventouse ont présenté des taux de bilirubine plus élevés que les autres à 24 heures $(114 \mu \mathrm{mol} / 1$ contre $96 \mu \mathrm{mol} / 1)$, à 48 heures (163 contre 141) et à 72 heures de vie (194 contre 144). $\mathrm{La}$ valeur de $\mathrm{p}$ est respectivement de $0,05,<0,025$ et

Mots-clés: Bilirubine, ictère, ventouse.

\section{Bibliography}

[1] BEARD, R., M. BRUDENELL, P. DUNN, D. FAIRWETHER (Eds.): The management of labour: Proceedings of the Third Study Group of the Royal College of Obstetricians and Gynecologists (1975) 257 was higher after vacuum extraction than after non instrumental delivery $(27.5 \%$ vs. $12.5 \%$; $p<0.04)$.

Analysis of our results unexpectedly indicated that oxytocin induction was generally associated with an attenuation of bilirubin levels after both vacuum extraction and spontaneous delivery.

The clinician attending newborn babies should be aware of the higher incidence of neonatal hyperbilirubinemia associated with vacuum extraction.

Die zugehörigen $\mathrm{p}$-Werte betrugen $0.05,<0.025$ und $<0.001$. Dieser Trend zeigte sich unabhängig davon, $o b$ die Geburt mit Oxytocin eingeleitet wurde oder nicht und auch unabhängig davon, ob mit Phototherapie behandelte Fälle in die Analyse miteinbezogen wurden oder nicht. Die Häufigkeit der mit Phototherapie behandelten Hyperbilirubinämien war nach Vakuumextraktionen größer als nach Sontangeburten $(27.5 \% \mathrm{zu} 12.5 \%$; p < 0.04).

Was unsere Analyse zeigte und wir nicht erwartet hatten, war, daß mit Oxytocin induzierte Geburten generell einen Abfall des Bilirubinspiegels sowohl nach Vakuumextraktionen wie auch nach Spontangeburten zur Folge hatten. Der Kliniker, der Neugeborene überwacht, sollte daran denken, daß Hyperbilirubinämien nach Vakuumextraktionen häufiger auftreten.
$<0,001$. Cette tendance se retrouve et pour les accouchements déclenchés au syntocinon et pour les accouchements spontanés, de même qu l'on incluse ou non à cette étude les cas avec photothérapie. L'incidence des hyperbilirubinémies nécessitant une photothérapie est plus grande après extraction par ventouse qu'après extraction non-instrumentale $(27,5 \%$ contre $12,5 \%, \mathrm{p}<0,04)$.

De façon inopinée, l'analyse des résultats montre que le déclenchement par ocytocine s'accompagne d'une diminution des taux de bilirubine à la fois lors des extractions par ventouse et à la fois lors des expulsions spontanées. Les cliniciens néonatologues doivent être au courant de l'incidence plus élevée des hyperbilirubinémies néonatales lors des extractions par ventouse.
[2] BIRD, G. E.: Modification of Malmström extractor. Brit. Med. J. 2 (1969) 526

[3] BUCHAN, B. C.: Pathogenesis of neonatal hyperbilirubinaemia after induction of labour with oxytocin. Brit. Med. J. 2 (1979) 1255 
[4] CALDER, A. A., V. A. MOAR, M. K. OUNSTED, M. C. TURNBULL: Increased bilirubin levels in neonates after induction of labour by intravenous prostaglandin $E_{2}$ or oxytocin. Lancet II (1974) 1339

[5] CHEW, W. C., I. L. SWANN: Influence of simultaneous low amniotomy and oxytocin infusion and other maternal factors on neonatal jaundice: a prospective study. Brit. Med. J. 1 (1977) 72

[6] DAVIES, D. P., R. GOMERSALL, R. ROBERTSON, D. P. GRAY, A. C. TURNBULL: Neonatal jaundice and maternal oxytocin infusion. Brit. Med. J. 3 (1973) 476

[7] D'SOUZA, S. W., P. BLACK, T. MACFARLANE: Fetal scalp damage and neonatal jaundice: A risk of routine fetal scalp electrode monitoring. J. Obstet. Gynecol. 2 (1982) 161

[8] D'SOUZA, S. W., P. BLACK, T. MACFARLANE, B. RICHARDS: The effect of oxytocin in induced labour on neonatal jaundice. Brit. J. Obstet. Gynec. 86: (1979) 133

[9] Dubowitz, L. M. S., V. DUbowitz, C. GoldBERG: Clinical assessment of gestational age in the newborn infant. J. Pediat. 77 (1970) 1

[10] FRIEDMAN, E. Z., M. R. SACHTLEBEN: Neonatal jaundice in association with osytocin stimulation of labour and operative delivery. Brit. Med. J. 1 (1976) 198

[11] GOULD, S. R., U. MOUNTROSE, D. J. BROWN, W. L. WHITEHOUSE, D. E. BARNARDO: Influence of previous oral contraception and maternal oxytocin infusion on neonatal jaundice. Brit. Med. J. 3 (1974) 228
[12] GREIS, J. B., J. BIENIARZ, A. SCOMMEGNA: Comparison of maternal and fetal effects of vacuum extraction with forceps or Cesearean deliveries. $\mathrm{Ob}$ stet. and Gynec. 57: (1981) 571.

[13] KAPPY, K. A.: Vacuum extractor. Clinics in Perinatology 8 (1981) 79

[14] MAISELS, M. J.: Neonatal jaundice. In: AVERY, G. B. (Ed.): Neónatalogy. Lippincott 1975

[15] MALMSTROM, T.: Vacuum extractor: An obstettrical instrument Acta Obstet. Gynecol. Scand. 33 (Suppl. 4) (1954) 3

[16] MALMSTRÖM, T., J. JANSSON: Use of vacuum extractor. Clin. Obstet. Gynecol. 8 (1965) 893

[17] PLAUCHE, W. C.: Vacuum extraction: Ùse in a community hospital setting. Obstet. and Gynec. 52 (1978) 287

[18] PLAUCHE, W. C.: Fetal cranial injuries related to delivery with the Malmström vacuum extractor. Obstet. and Gynec. 53 (1979) 750

[19] ROSZKOWSKI, J., F. BORKOWSKI, J. KRETOWICZ: Use of vacuum extractor in fetal distress. Amer. J. Obștet. Gynec. 87 (1963) 253

[20] SCHENKER, J. G., D. M. SERR: Comparative study of delivery by vacuumiextractor and forceps. Amer. J. Obstet. Gynec. 98 (1967) 32

[21] SIVASURIYA, M., K. L. TAN, Y. M. SALMON, S. M. M. KARIM: Neonatal serum bilirubin levels in spontaneous and induced labour. Brit. J. Obstet. Gynec. 85 (1978) 619

Received May 4, 1982. Accepted August 12, 1982.

Ilan Arad, M.D.

Dept. of Pediatrics

Hadassah University Hospital

Ein Karem

P.O.Box 12000

Jerusalem / Israel 